\title{
Influence of Cover Defects on the Attenuation of Radon with Earthen Covers
}

Prepared by D. R. Kalkwarf, D. W. Mayer

Pacific Northwest Laboratory

Operated by

Battelle Memorial Institute

Prepared for

U.S. Nuclear Regulatory

Commission 


\section{NOTICE}

This report was prepared as an account of work sponsored by an agency of the United States Government. Neither the United States Government nor any agency thereof, or any of their employees, makes any warranty, expressed or implied, or assumes any legal liability of responsibility for any third party's use, or the results of such use, of any information, apparatus, product or process disclosed in this report, or represents that its use by such third party would not infringe privately owned rights.

\section{Availability of Reference Materials Cited in NRC Publications}

Most documents cited in NRC publications will be available from one of the following sources:

1. The NRC Public Document Room, 1717 H Street, N.W. Washington, DC 20555

2. The NRC/GPO Sales Program, U.S. Nuclear Regulatory Commission, Washington, DC 20555

3. The National Technical Information Service, Springfield, VA 22161

Although the listing that follows represents the majority of documents cited in NRC publications, it is not intended to be exhaustive.

Referenced documents available for inspection and copying for a fee from the NRC Public Document Room include NRC correspondence and iriternat NRC memoranda; NAC Office of Inspection and Enforcement bulletins, circulars, information notices, inspection and investigation notices; Licensee Event Reports; vendor reports and correspondence; Commission papers; and applicant and licensee documents and correspondence.

The following documents in the NUREG series are available for purchase from the NRC/GPO Sales Program: formal NRC staff and contractor reports, NRC-sponsored conference proceedings, and NRC booklets and brochures. Also available are Regulatory Guides, NRC reguiations in the Code of Federal Regulations, and Nuclear Regulatory Commission Issuances.

Documents available from the National Technical Information Service include NUREG series reports and technical reports prepared by other federal agencies and reports prepared by the Atomic Energy Commission, forerunner agency to the Nuclear Regulatory Commission.

Documents available from public and special technical libraries include all open literature iterns, such as books, journal and periodical articles, and transactions. Federal Register notices, federal and state legislation, and congressional reports can usually be obtained from these libraries.

Documents such as theses, dissertations, foreign reports and translations, and non-NRC conference proceedings are available for purchase from the organization sponsoring the publication cited.

Single copies of NRC draft reports are available free upon written request to the Division of Technical Information and Document Control, U.S. Nuclear Regulatory Commission, Washington, DC 20555.

Copies of industry codes and standards used in a substantive manner in the NRC regulatory process are maintained at the NRC Library, 7920 Norfolk Avenue, Bethesda, Maryland, and are available there for reference use by the public. Codes and standards are usually copyrighted and may be purchased from the originating organization or, if they are American National Standards, from the American National Standards institute, 1430 Broadway, New York, NY 10018.

GPO Printed copy price: $\$ 3.75$ 
NUREG/CR-3395

PNL-4776

RU

\section{Influence of Cover Defects on the Attenuation of Radon with Earthen Covers}

Manuscript Completed: August 1983

Date Published: November 1983

Prepared by

D. R. Kalkwarf, D. W. Mayer

Pacific Northwest Laboratory

Richland, WA 99352

Prepared for

Division of Health, Siting and Waste Management

Office of Nuclear Regulatory Research

U.S. Nuclear Regulatory Commission

Washington, D.C. 20555

NRC FIN B2269 


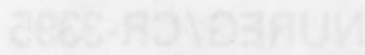

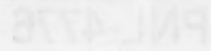
$(4)$ 


\section{ABSTRACT}

Experimental and theoretical evaluations of radon flux through laboratoryscale defective soil columns are presented together with a survey of literature on the formation and prevention of defects in soil covers. Defects are defined to be large-scale discontinuities in the homogeneity of soil covers. This report focuses on air-filled, centimeter-scale defects that are most probable in earthen covers for attenuating radon emission from uranium-mill tailings. Examples include shrinkage and erosion cracks, erosion piping, animal burrows and air channels formed by the biodegradation of vegetation roots. Calculations based on mathematical models indicated that collections of defects which could increase the radon flux from an earthen cover by a factor of two would be easily detected by visual inspection. However, these models ignore airturbulence in the defect and drying of the soil around the defect. Laboratory measurements showed that turbulent diffusion of radon occurred through defects as narrow as $0.3 \mathrm{~cm}$ when subjected to a transverse air velocity of 1 to 6 miles per hour at the surface. Both turbulence and more-rapid drying of soil can accelerate radon flux to the cover surface. Consequently, recommended methods to inhibit defect formation should be applied. 



\section{CONTENTS}

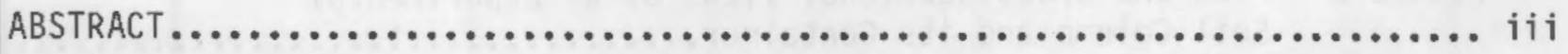

ACKNOWLEDGEMENTS $\ldots \ldots \ldots \ldots \ldots \ldots \ldots \ldots \ldots \ldots \ldots \ldots \ldots \ldots \ldots \ldots \ldots \ldots \ldots \ldots \ldots \ldots$

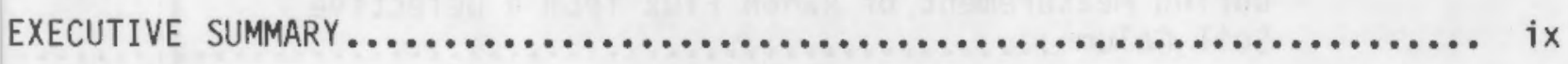

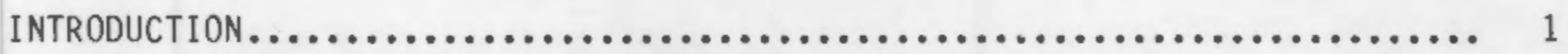

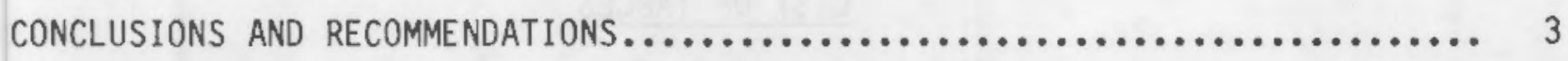

ESTIMATION OF THE UNCERTAINTY IN CALCULATED FLUX VALUES $\ldots \ldots \ldots \ldots \ldots \ldots \ldots$

THEDRETICAL EQUATIONS FOR PREDICTING RADON FLUX FROM DEFECTIVE COVERS..... 7

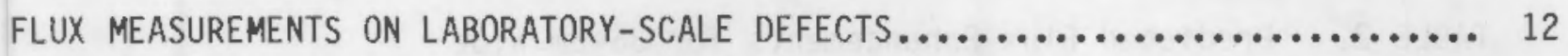

Preparation of Soil Columns............................ 12

Measurement of Radon Flux............................... 12

Results of the Laboratory Measurements..................... 15

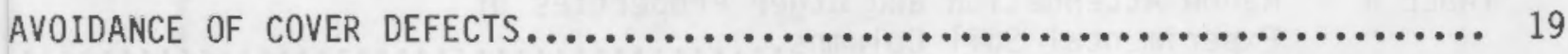

Selection of the Cover Soil $\ldots \ldots \ldots \ldots \ldots \ldots \ldots \ldots \ldots \ldots \ldots \ldots \ldots \ldots \ldots \ldots \ldots$

Design and Application of the Cover......................... 20

Control of Vegetation Roots.............................. 20

Control of Animal Burrows............................... 21

REFERENCES ............................................. 22 


\section{LIST OF FIGURES}

FIGURE 1. Spacing of 2.0-cm Wide, 75-cm Deep Rectangular Cracks Required to Increase the Radon Surface Flux to Twice that from a 100-m Deep Defect-free Earthen Cover..........................................

FIGURE 2 Plan and Cross-Sectional Views of an Experimental Soil Column and its Container.

FIGURE 3 Cross-Sectional View of a Charcoal Trap in Place During Measurement of Radon Flux from a Defective Soil Column.

\section{LIST OF TABLES}

TABLE 1 Change in Calculated Radon Flux Caused by a Three-fold Reduction in the Diffusion Coefficient for Radon in an Earthen Cover............................

TABLE 2 Predicted Flux Enhancements for $36-\mathrm{cm}$ Wide Earthen Covers with Various Size Rectangular

Slotted Defects......................................

TABLE 3 Interdefect Spacing Required to Reduce the

Average Flux Enhancement to a Factor of Two................. 9

TABLE 4 Radon Attenuation and 0ther Properties of Experimental Soil Columns............................. 16

TABLE 5 Comparison of Theoretical and Experimental Values of $\mathrm{J}_{10} / \mathrm{J}_{0}$ and $\mathrm{C}_{\mathrm{g}}$ for Defective Soil Columns. 


\section{ACKNOWLEDGEMENTS}

The authors wish to acknowledge the careful assistance of C. Veverka, Jr. and J. D. Forsythe in the laboratory experiments reported here, and the helpful discussions with $\mathrm{Dr}$. Glendon Gee of the Pacific Northwest Laboratory. 


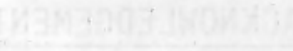
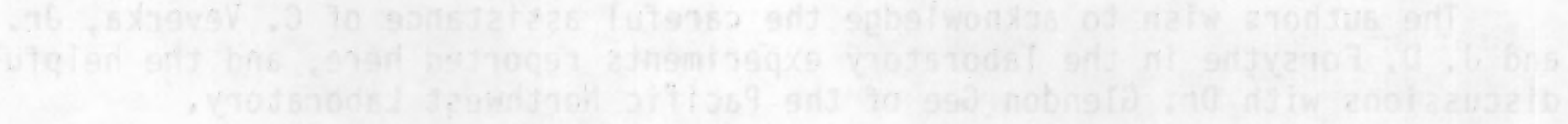


\section{EXECUTIVE SUMMARY}

This study had two purposes. One was to estimate the size and spacing of defects in an earthen cover for uranium-mill tailings that could significantly increase the radon flux from the cover. The other purpose was to recommend practicable methods to avoid defect formation. Defects are defined here to be any large-scale discontinuities in the homogeneity of an earthen cover. This report focuses on air-filled, centimeter-scale defects that are most probable in earthen covers constructed at tailings sites. Examples include shrinkage and erosion cracks, erosion piping, animal burrows and air channels formed by the biodegradation of dead vegetation roots.

It was concluded that defects in an earthen cover for uranium-mill tailings should be limited to those which do not increase the average radon flux from the cover by more than a factor of two. This factor was estimated to be the uncertainty in flux values calculated with the best empirically derived radon diffusion coefficients currently available. At present, mathematical models based on molecular diffusion theory provide the best way to estimate the size and spacing of cover defects which would enhance radon flux by a specified amount. Calculations based on these models suggest that a collection of cover defects which enhance radon flux by a factor of two or more will be easily recognized visually, e.g., cracks at least $2-\mathrm{cm}$ wide, spaced less than $1 \mathrm{~m}$ apart and penetrating $75 \%$ of the cover thickness. The models, however, have only been applied to defects of simple geometry in which the possibilities of turbulent diffusion in the defects and continual drying of the soil around the sides have been ignored. Both of these effects will enhance radon transport from the cover, and results of flux measurements on laboratory-scale soil columns suggested that turbulence occurs even in cracks as narrow as $0.3 \mathrm{~cm}$ when subjected to a transverse air velocity of 0.5 to 3 meters per second (1 to 6 miles per hour) at the surface. Thus, serious enhancement of radon flux could occur with systems of defects that are less obvious than those predicted by the models; and methods to avoid the formation of defects should be applied in view of this uncertainty.

A literature search revealed several practicable techniques for preventing defects in an earthen cover. Standard shrinkage tests should be applied to samples of the candidate soil before it is used for a cover in order to predict and avoid the possibility of forming cracks of undesirable width upon drying. In particular, soils rich in smectic clays should not be used as covers because of their tendency to form cracks. Sodic soils should also be avoided since they are particularly susceptible to water erosion and development of piping features such as large tunnels and holes. References are given to procedures for identifying both of these types of soils. Shrinkage cracks and erosion should also be inhibited by careful design and construction of the cover so that its moisture content can be maintained at the desired value and runoff of precipitation will not cause significant erosion. References are given to such procedures and to methods for inhibiting animal and plant intrusions into the cover with sustained-release herbicides, rodenticides and layers of stones. 

Earthen covers have been recommended as effective means for reducing the radon flux from uranium-mill tailings to acceptable values (U.S. Nuclear Regulatory Commission 1980). The soil increases the diffusion path of radon to the atmosphere and provides time for radioactive decay of ${ }^{222} \mathrm{Rn}$ (half -1 ife $=3.82 \mathrm{~d}$ ) within the cover. The thickness of soil required to reduce the radon flux to prescribed levels will be determined by calculation (U.S. Nuclear Regulatory Commission 1980); and methods are available to calculate this thickness for an earthen cover that is free from defects (Rogers and Nielson 1981). Defects are defined here to be large-scale discontinuities in the homogeneity of an earthen cover. This report will focus on air-filled, centimeter-scale defects that are most probable in earthen covers for attenuating radon from uranium-mill tailings. Examples include shrinkage and erosion cracks, erosion piping, animal burrows and air channels formed by the biodegradation of dead vegetation roots.

Conceptually, air-filled defects in an earthen cover appear capable of imparing its ability to attenuate radon emission. They provide paths for morerapid molecular diffusion of radon to the atmosphere, allow turbulent diffusion of radon from the cover and cause the homogeneous regions of soil near the defect to dry faster, enhancing radon transport in those regions also. Turbulent diffusion of radon is of particular concern since transport coefficients ranging from 100 to $10,000 \mathrm{~cm}^{2} / \mathrm{s}$ have been estimated for gas movement in air near the soil surface, i.e. values much larger than the molecular diffusion coefficient for radon in air (Kimball 1983).

The degree of impairment caused by the defect will depend on numerous factors. The size and shape of the defect and its extent of penetration into the cover are clearly significant. Moreover, the degree of impairment will depend on the attenuation required at the specific tailings pile. If radon emission must be reduced greatly to meet regulatory requirements, a large concentration gradient for radon must be maintained across the cover. Any hole in such a cover will be the site for rapid efflux of radon to relieve that concentration gradient. On the other hand, if maintenance of a large concentration gradient is not required, the importance of defects diminishes since the concentration gradient driving the radon toward the defect is not so great. Finally, since the average flux over the covered area is the significant parameter from the regulatory point of view, the spacing of defects is of major importance.

The purpose of this study was to estimate the size and spacing of defects that could significantly increase the radon flux from covered tailings and to recommend practicable methods to avoid their formation. In this study, a significant increase was considered to be any increase beyond the limit of uncertainty in the calculated flux values themselves. Estimation of that uncertainty is the first problem considered in this report. Next, theoretical equations that have been proposed to calculate the racion flux from defective covers are examined in order to obtain some quantitative perspective of the problem. The results of flux measurements on experimental defects in 
laboratory-scale soil columns are then reported and used to test the validity of the theoretical equations and to examine factors that promote radon flux from a cover defect. Finally, and perhaps of most practical value, the results of a literature search for methods to prevent the formation of defects are presented. 


\section{CONCLUSIONS AND RECOMMENDATIONS}

Defects in an earthen cover for uranium-mill tailings should be limited to those which collectively do not increase the average radon flux from the cover by more than a factor of two. This factor was estimated to be the uncertainty in flux values calculated with the best empirically derived radon diffusion coefficients currently available. At present, mathematical models based on molecular diffusion theory provide the best way to estimate the size and spacing of cover defects which would enhance radon flux by a specified amount. Calculations based on these models suggest that a collection of cover defects which enhance radon flux by a factor of two or more will be easily recognized, e.g., cracks at least $2-\mathrm{cm}$ wide, spaced less that $1 \mathrm{~m}$ apart and penetrating $75 \%$ of the cover thickness. The models, however, have only been applied to defects of simple geometry in which the possibilities of turbulent diffusion in the defects and continual drying of the soil around the sides have been ignored. Both of these effects will enhance radon transport from the cover, and results of flux measurements on laboratory-scale soil columns suggested that turbulence occurs even in cracks as narrow as $0.3 \mathrm{~cm}$ when subjected to a transverse air velocity of 1 to 6 miles per hour at the surface. Thus, serious enhancement of radon flux could occur with systens of defects that are less obvious than those predicted by models; and methods to avoid the formation of defects should be applied in view of this uncertainty. defects:

The following techniques are recommended to avoid the formation of

1. Avoid soils that form shrinkage cracks. These include soils that are rich in smectites, i.e., aluminosilicate clays which form wide and deep shrinkage cracks. They can be detected by standard soil shrinkage tests or by a variety of tests that characterize clays.

2. Avoid soils that are eroded easily by precipitation runoff. These include sodic soils, i.e., soils containing unusually high concentrations of leachable sodium ion. They can be identified by their sodium adsorption ratios being greater than 15.

3. Use care in the design and application of the cover. Establish that the moisture content of the soil can be maintained for long periods of time under the climatic conditions at the site. Cover the earthen diffusion barrier with a layer of soil to act as an evaporation barrier.

4. Use sustained-release herbicides to control the root length of plants used for revegetation of the cover.

5. Use layers of stones or sustained-release rodenticides to control the intrusion of animal burrows into the tailings. 
In order to judge the quantitative significance of a flux increase caused by a cover defect, the limit of uncertainty in calculated flux values themselves must be considered. Radon fluxes will usually be calculated with radon diffusion coefficients derived from empirical relationships, and their accuracy will depend on the validity of these relationships. At present, the relationship that best fits the available experimental data is that of Rogers and Nielson (1982):

$$
D=0.070 \exp \left[-4\left(m-m P^{2}+m^{5}\right)\right]
$$

where $D=$ the diffusion coefficient of radon in the total pore space of the bulk soil $\left(\mathrm{cm}^{2} \cdot \mathrm{s}^{-1}\right)$

$m=$ the moisture saturation of the soil (the fraction of total pore space filled with moisture)

$P=$ the dry porosity of the soil (dimensionless)

Equation 1 was found to predict the radon diffusion coefficients of 34 candidate soils for covering uranium-mill tailings to within a factor of three (Silker and Kalkwarf 1983).

In order to estimate the effect of a three-fold change in $D$ on the radon flux, the following flux equation was used (U.S. Nuclear Regulatory Commission 1980):

$$
J_{c}=\frac{2 J_{t} \exp \left(-k_{c} x\right)}{1+\frac{P_{c}}{P_{t}}\left(\frac{D_{c}}{D_{t}}\right)^{1 / 2}+\left[1-\frac{{ }_{c}}{P_{t}}\left(\frac{D_{c}}{D_{t}}\right)^{1 / 2}\right] \exp \left(-2 k_{c} x\right)}
$$

where $J_{C}=$ the radon flux from the cover $\left(p C i \cdot \mathrm{cm}^{-2} \cdot \mathrm{s}^{-1}\right)$

$\mathrm{J}_{\mathrm{t}}=$ the radon flux from the bare tailings $\left(\mathrm{pCi} \cdot \mathrm{cm}^{-2} \cdot \mathrm{s}^{-1}\right)$

$k_{C}=(\lambda / 0)^{1 / 2}\left(\mathrm{~cm}^{-1}\right)$

$x=$ the depth of the cover $(\mathrm{cm})$

$P_{t}=$ the dry porosity of the tailings (dimensionless)

$P_{C}=$ the dry porosity of the cover soil (dimensionless) 


$$
\begin{aligned}
& \begin{aligned}
& D_{t}= \text { the diffusion coefficient of radon in the total pore space of } \\
& \text { the tailings }\left(\mathrm{cm}^{2} \cdot \mathrm{s}^{-1}\right)
\end{aligned} \\
& \begin{aligned}
& D_{c}= \text { the diffusion foefficient of radon in the total pore space of the } \\
& \text { cover soil }\left(\mathrm{cm}^{2} \cdot \mathrm{s}^{-1}\right)
\end{aligned}
\end{aligned}
$$

The change in flux caused by a three-fold reduction in $D$ can then be expressed by the ratio, $J_{c}^{\prime} / J_{c}$, where $J_{c}^{\prime}$ is the flux calculated with a value of $D_{c}^{\prime}=$ $D_{c} / 3$. The value for the diffusion coefficient of radon in the cover soil enters into several terms of Equation 2 so that some simplifying, yet reasonable, approximations must be made in order to evaluate its influence. These are listed below:

$$
\begin{gathered}
P_{t}=P_{C} \\
D_{t}=D_{c}=3 D_{C}^{\prime}
\end{gathered}
$$

Making these substitutions, $\mathrm{J}^{\prime}{ }_{\mathrm{c}} / \mathrm{J}$ can be expressed as:

$$
\frac{J_{c}^{\prime}}{J_{c}}=\frac{2 \sqrt{3} \exp \left(-k_{c}^{\prime} x+k_{c} x\right)}{\sqrt{3}+1+(\sqrt{3}-1) \exp \left(-2 k_{c}^{\prime} x\right)}
$$

Values for this ratio will depend on $x$ and $D_{C}$, and representative values for

\begin{tabular}{|c|c|c|}
\hline$\left(\mathrm{cm}^{D}{ }^{D} g_{s}\right)$ & $\begin{array}{c}x \\
(\mathrm{~cm})\end{array}$ & $\mathrm{J}_{\mathrm{c}}^{\prime} / \mathrm{J}_{\mathrm{c}}$ \\
\hline 0.06 & 100 & 0.8 \\
\hline 0.06 & 200 & 0.5 \\
\hline 0.03 & 100 & 0.7 \\
\hline 0.03 & 200 & 0.4 \\
\hline 0.01 & 100 & 0.4 \\
\hline 0.01 & 200 & 0.1 \\
\hline
\end{tabular}
these quantities at covered tailings piles are listed in Table 1.

\section{TABLE 1}

CHANGE IN CALCULATED RADON FLUX CAUSED BY A THREE-FOLD REDUCTION IN THE DIFFUSION COEFFICIENT FOR RADON IN AN EARTHEN COVER 
The values obtained for $J_{c}^{\prime} / J_{C}$ show that a three-fold change in $D_{C}$ will cause about a two-fold change in the calculated radon flux from the cover. Thus, it was concluded that values for $J_{C}$, calculated with empirical values of $D_{C}$, will have an uncertainty of around a factor of two and that defects must enhance radon flux by at least a factor of two in order to be considered significant. 
Two techniques have been published for calculating the radon flux from defective covers over uranium-mill tailings. The technique most directly applicable to defects in earthen covers is that of Mayer and Zimmerman (1981). This technique is based on a general differential equation for molecular diffusion of radon in soils (Nelson et al., 1980) and utilizes a computer code known as RADMD (Radioactive Diffusion in Multidimensions) to integrate the differential equation for selected boundary conditions (Mayer et al., 1981). More recently, another technique was proposed by Landman, with particular application to defective concrete covers such as house foundations built on tailings material (Landman 1982, Landman and Cohen 1983). This technique assumes that radon can only penetrate the cover through defects in the form of air-filled cracks in the concrete. The resulting differential equations are solved by analytical techniques. Mathematical replacement of the actual crack dimensions by a line source giving the same total radon flux allows other transport mechanisms for radon, such as advection and turbulent diffusion, to be included in the treatment. Both techniques indicate significant increases in radon flux from the defects described in their examples, and so it is important to understand the geometries of these examples so that the results can be related to possible defect geometries at a covered tailings pile.

Mayer and Zimmerman predicted the average radon flux from covers containing one of several sizes of rectangular, air-filled defects. In each case, the system considered was a $36-\mathrm{cm}$ wide strip of uranium-mill tailings, 6 meters thick covered by 1 meter of a clay/gravel mix. The radon flux from the bare tailings was calculated to be $856 \mathrm{pCi} / \mathrm{m}^{2} \mathrm{~s}$ and a value of $0.0029 \mathrm{~cm}^{2} / \mathrm{s}$ was used for the diffusion coefficient of radon in the compacted cover soil. This latter value is at the low end of the range predicted for candidate cover soils in the western United States (Silker and Kalkwarf 1983). The defects were slots running the entire length of the cover and having one of three different widths, $1.5-\mathrm{cm}$ wide penetrating the entire cover, 2-cm wide penetrating threequarters of the cover thickness and $3-\mathrm{cm}$ wide penetrating half of the cover thickness. Values were calculated for the radon flux directly over the slot, $\mathrm{J}_{s}$, the flux averaged over only the covered portion of the strip, $\mathrm{J}_{c}$, the flux averaged over both the slot and the covered portion of the strip, $\mathrm{J}_{\mathrm{sc}}^{\mathrm{C}}$ and the flux over a defect-free strip of cover, $J_{n}$. These values and other pcarameters of the system are listed in Table 2. It was noted that the flux $J_{c}$ was generally less than $J_{n}$ since enhanced flux from the slot reduced the concentration gradient in the cover, resulting in slower diffusion of radon to the surface. 
TABLE 2

PREDICTED FLUX ENHANCEMENTS FOR 36-CM WIDE EARTHEN COVERS WITH VARIOUS SIZE RECTANGULAR SLOTTED DEFECTS

(Mayer and Zimmerman 1981)

Cross-Sectional Slot Dimensions (m)

$0.015 \times 1.00$

$0.020 \times 0.75$

$0.030 \times 0.50$
Cover Penetration 100 75

50
Flux Over Width of slot Width of Cover 0.042

0.056

0.083 \begin{tabular}{l} 
the $\mathrm{Slot}=\mathrm{J}$ \\
$\left(\mathrm{pC} \mathrm{C} / \mathrm{m}^{2} \mathrm{~s}\right)$ \\
\hline
\end{tabular} 4167 638

222
Flux Over $\mathrm{J}_{\mathrm{SC}}$ * the Cover $=J$
$\left(\mathrm{pCi} / \mathrm{m}^{2} \mathrm{~s}\right)$$\quad \frac{\mathrm{sc}}{J_{n}}$ 31

\section{9}

1.1 6

0.6 3

$$
\begin{aligned}
\frac{{ }_{s c}}{J_{s c}} & =\frac{\text { average flux from a strip of cover containing the slot }}{\text { average flux from a defect-free strip of cover }} \\
J_{n} & =6.4 \mathrm{pCi} / \mathrm{m}^{2} \mathrm{~s}
\end{aligned}
$$

For each of these defect systems, the radon flux directly over the slot was calculated to be very large compared with the flux from a defect-free cover; and even the radon flux averaged over the entire width of the covered strip is significantly larger than the flux from a defect-free cover.

If defects are spaced farther apart on covered tailings, the influence on the average flux will be diminished since the surface area of the defects will represent a smaller fraction of the total surface. Thus, it is instructive to calculate the spacing between defects that would reduce the average flux enhancement to the uncertainty in the calculated flux from a defect-free cover, i.e., a factor of two. This new spacing is related to the flux by the equation

$$
w^{\prime} \bar{j}_{s c}^{\prime}=w_{s c}+\left(w^{\prime}-w\right) \bar{j}_{c}
$$

where: $\bar{j}_{s c}=$ the flux from a defective cover averaged over a width, $w$ $\bar{J}_{\text {Sc }}^{\prime}=\underset{\text { width }}{\text { the } W^{\prime}}$ from a defective cover averaged over a larger

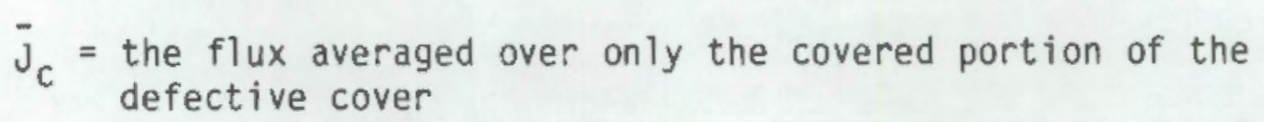


For $\bar{J}_{S C}^{\prime}=2 J_{n}$, Equation 6 reduces to:

$$
w^{\prime}=\frac{w\left(J_{s c}-J_{c}\right)}{2 J_{n}-J_{c}}
$$

Applying this equation to the data in Table 2 gives the values shown in the middle column of Table 3 .

For this calculation the values for $\bar{j}_{c}$ are taken to be the average surface fluxes from the covered portion of the defective covers reported by Mayer and Zimmerman. This is an accurate assumption if the defects are on $36 \mathrm{~cm}$ centers, the spacing used in the defect analysis performed by Mayer and Zimmerman. This assumption is still reasonable if the defects are reasonably close to the $36 \mathrm{~cm}$ spacing. If the defects are far apart the average surface flux from the covered portion of a defective cover will approach the surface flux obtained when there are no defects, $J_{n}$. The calculations were repeated using $J_{n}$ in place of $\mathrm{J}_{\mathrm{c}}$.

Equation (7) then becomes

$$
W_{2}^{\prime}=\frac{W\left(J_{s c}-J_{n}\right)}{J_{n}}
$$

This second set of calculations are shown in the last column of Table 3 . The spacing widths reported for each defect geometry provide the bounds within which the given defect would yield a significant increase in the radon flux through a cover.

TABLE 3

INTERDEFECT SPACING REQUIRED TD REDUCE THE AVERAGE FLUX

\begin{tabular}{|c|c|c|}
\hline $\begin{array}{c}\text { Cross-Sectional } \\
\text { Slot Dimensions } \\
(\mathrm{m})\end{array}$ & $\begin{array}{c}\text { Spacing }(\mathrm{m}) \\
\text { Based on } \\
\mathrm{J}_{\mathrm{S}} \\
\end{array}$ & $\begin{array}{c}\text { Spacing (m) } \\
\text { Based on } \\
J_{n} \\
\end{array}$ \\
\hline $0.015 \times 1.00$ & 11.7 & 10.8 \\
\hline $0.020 \times 0.75$ & 1.1 & 1.8 \\
\hline $0.030 \times 0.50$ & 0.5 & 0.7 \\
\hline
\end{tabular}
ENHANCEMENT TO A FACTOR OF TWO 
Some appreciation for the spatial frequency of defects required to increase the average flux by a factor of two can be seen in Figure 1, where the pattern of slotted defects, $2 \mathrm{~cm}$ in width and penetrating 75\% of the cover, is superimposed on a tailings cover $100 \mathrm{~m}^{2}$ ( 0.2 acre) in size. Such covers should be easily recognized as defective. For covers with a lower frequency of such defects, the flux averaged over the entire area is within the uncertainty in the flux calculations themselves.

Although the procedure of Landman (1982) was designed to treat cracks in concrete slabs built over uranium mill tailings, an example shows that it predicts radon-flux relationships similar to those calculated by Mayer and Zimmerman. Landman expresses his results in terms of ratios of the radon flux averaged across a cover slab to the radon flux from the bare tailings. For a radon-impermeable concrete slab, 10-cm thick and containing a 1-cm wide crack, this ratio was calculated to be 0.26 . In this case, the ratio of the crack width to the total width of the slab was 0.01 . The cover-penetrating example of Mayer and Zimmerman discussed above is similar in that a 1.5-cm wide crack penetrates a highly attenuating cover $\left(\mathrm{J}_{n} / \mathrm{J}_{t}=0.007\right)$. For a ratio of crack widtb to total cover width of 0.04 , the radon flux averaged across the cover was $J_{\mathrm{sf}}=199 \mathrm{pCi} / \mathrm{m} \mathrm{s}$ and the radon flux averaged across the bare tailings was $\mathrm{J}=855 \mathrm{pCi} / \mathrm{m}^{2} \mathrm{~s}$ or a ratio of $\mathrm{J}_{\mathrm{sc}} / \mathrm{J}_{\mathrm{t}}=0.23$. Although the two examples and flux predictions are not identical the similarities suggest that the two procedures are equally valid for defects of this type. 


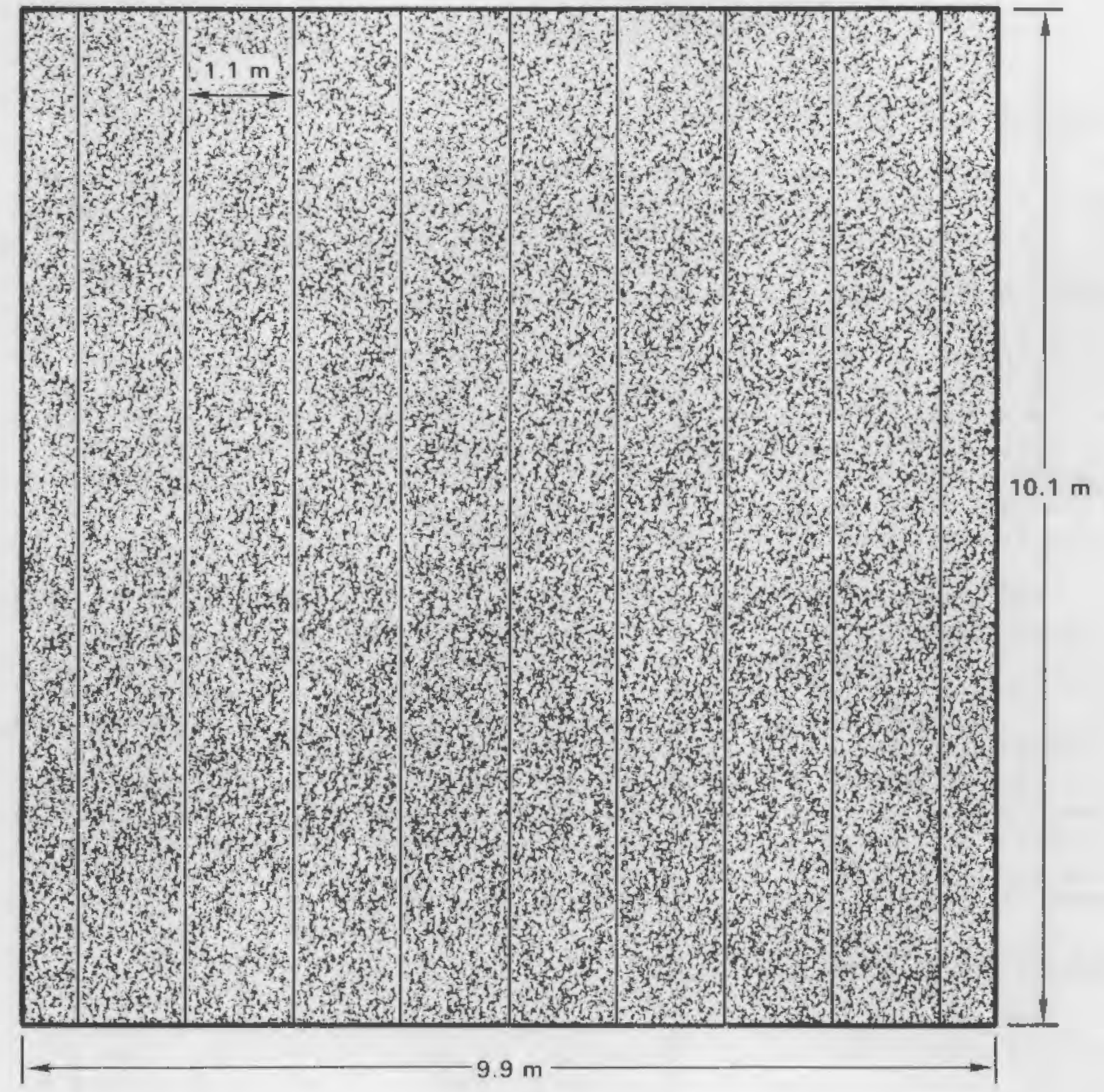

FIGURE 1. Spacing of 2.0-cm Wide, 75-cm Deep Rectangular Cracks Required to Increase the Radon Surface Flux to Twice that from a 100-cm Thick Defect-Free Earthen Cover 


\section{FLUX MEASUREMENTS ON LABORATORY-SCALE DEFECTS}

\section{Preparation of Soil Columns}

In order to better understand the influence of defects on radon flux, small soil columns containing rectangular, air-filled defects were examined in the Radon Attenuation Test Facility described earlier (Silker 1981). The soil columns were contained in cylindrical shells of Lucite which were sealed to a base containing radium salts deposited on a glass fiber filter. The seal was a rubber, quad-ring gasket compressed between the soil container and the base by metal screws. Cross-sectional and plan views of a typical assembly are shown in Figure 2. The soil columns were $14-\mathrm{cm}$ wide and $10-\mathrm{cm}$ high. The defects were air-filled slots spanning a diameter of the soil column and penetrating the soil to various depths. Slots with widths ranging from 0.3 to $1.5 \mathrm{~cm}$ were examined. Figure 2 shows an optional glass fiber filter at the top of the soil container. This was used in some experiments to inhibit turbulent diffusion of radon from a defect and was not found to attenuate the radon flux.

The columns with defects were prepared by compressing soil with a measured moisture content around a metal or plastic form with the same size as the desired slot. After the soil was packed to the desired bulk density, the form was carefully slipped out of the column, leaving an air-filled slot in its place. The soil used in these experiments was a mixed silty sand-clay sand, designated as Soil No. 3-A in an earlier publication which described its physical properties (Silker and Kalkwarf 1983). It is a candidate soil for covering tailings at a uranium mill in the western United States. For each defective soil column, a homogeneous soil column was also prepared with the same overall dimensions, bulk density and moisture content. These columns served as controls for the radon-flux measurements.

Measurement of Radon Flux

The radon flux emerging from the top of each column was evaluated by collecting the radon on beds of charcoal for measured periods of time. First the soil column was covered with a bed of charcoal for about 15 minutes in order to stabilize the radon flux in the space above the soil. This charcoal bed was then carefully replaced with a duplicate which was allowed to adsorb the radon flux for exactly 5 minutes. This procedure was repeated with two additional beds of charcoal in succession, and the 3 samples were then analyzed for adsorbed radon by counting its daughter, $214 \mathrm{Bi}$, with a gamma-ray spectrometer. Each bed contained $300 \mathrm{~cm}^{3}$ of coarse coconut charcoal, 6 to 20 mesh, packed to a depth of $2.4 \mathrm{~cm}$. The position of the bed during measurement is shown in Figure 3. Measurements with two beds stacked on top of the soil column showed that over $99.98 \%$ of the radon flux was adsorbed on the lower bed. The radon flux was calculated by dividing the average amount of adsorbed radon by the collection time and the cross-sectional area of the soil column.

Soil columns with defects and the corresponding control columns were examined under identical atmospheric conditions. Five bases, each with its own radon source, were available at any given time to accomodate the soil columns. 


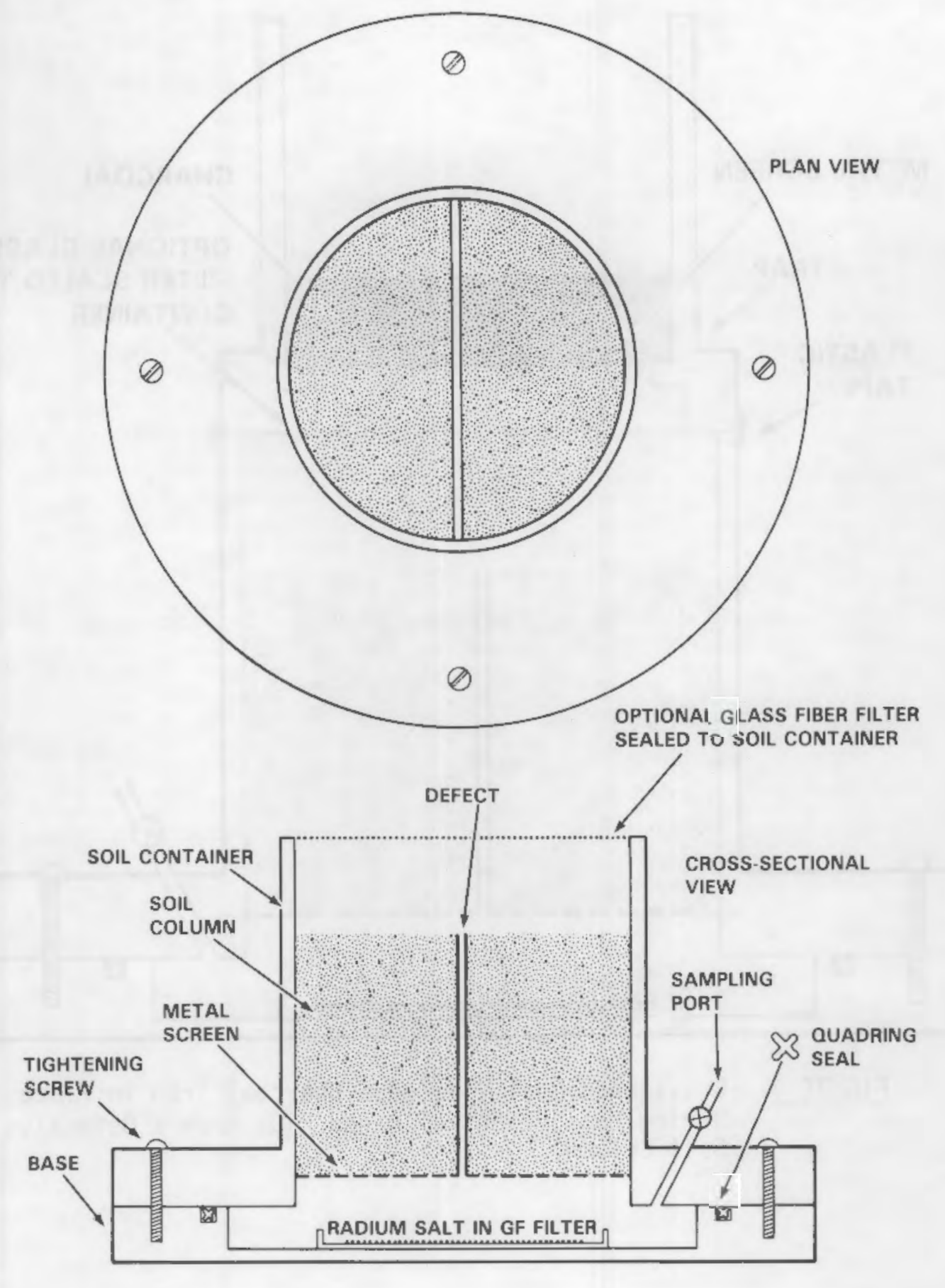

FIGURE 2. Plan and Cross-Sectional Views of an Experimental Soil Column and Its Container 


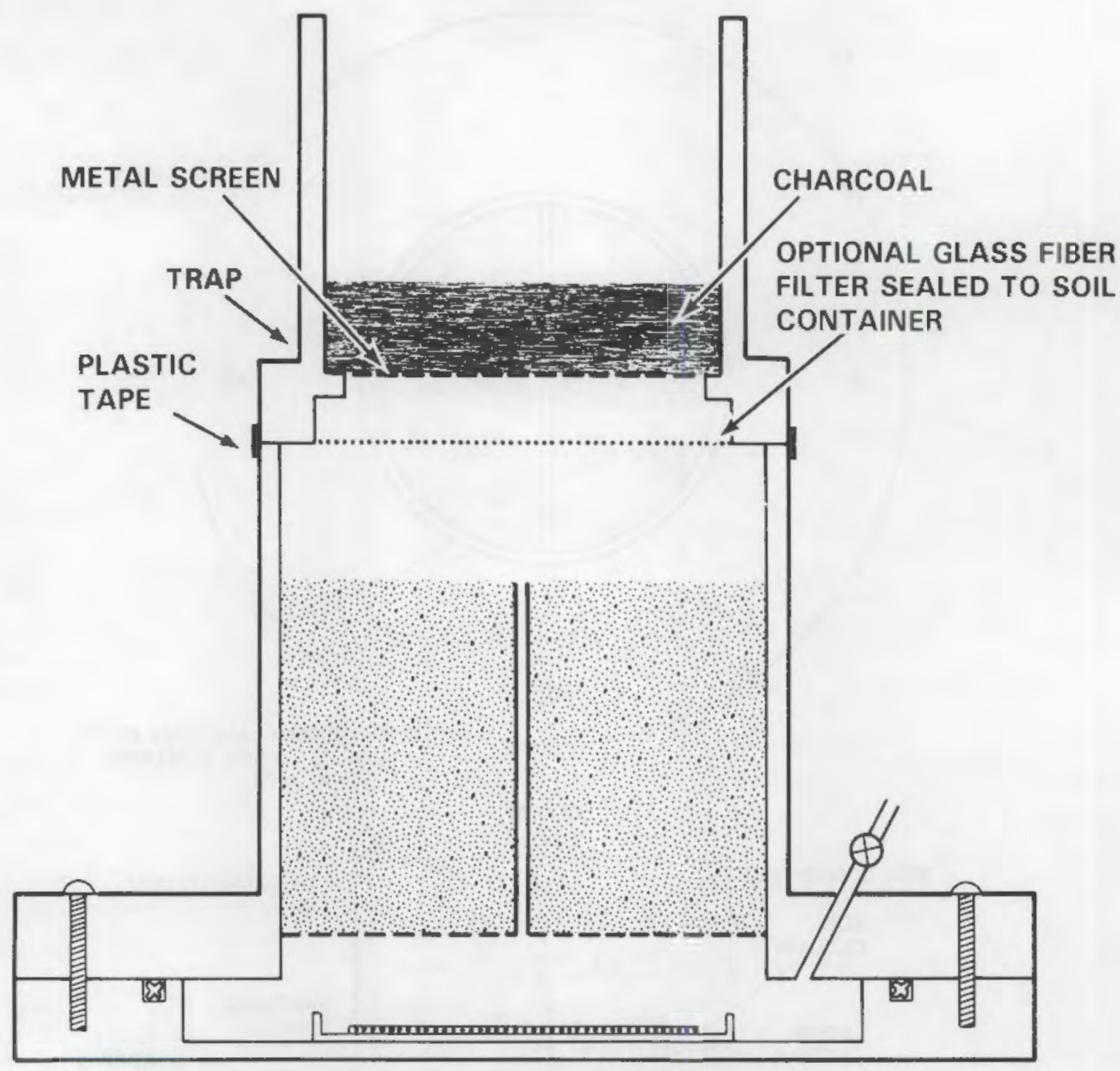

FIGURE 3. Cross-Sectional View of a Charcoal Trap in Place During Measurement of Radon Flux from a Defective Soil Column. 
Each set of five columns and bases were placed at the face of a laboratory hood, and the velocity of air passing over the tops of the columns was measured with a flowmeter. The velocities were found to range from 1 to 6 miles per hour, simulating possible wind speeds across a tailings pile. The radon flux, $J_{0}$, at the bottom of each soil column was evaluated indirectly by utilizing a reference column of dry Dunite sand with a known radon diffusion coefficient. The reference column was sealed to each source in turn, and the radon concentration, $C_{g}$, in the reservoir gas was measured at equilibrium. The quantities, $C_{g}$ and $J_{0}$, are related by the equation (Silker and Kalkwarf 1983):

$$
J_{0}=\frac{C_{g}(P-0.74 \theta)}{(k / \lambda) \tanh (k x)}
$$

where $J_{0}=$ the radon flux in the soil-retaining shell with no soil in place $\left(p C i \cdot \mathrm{Cm}^{-2} \cdot \mathrm{s}^{-1}\right)$

$\mathrm{C}_{\mathrm{g}}=$ the radon concentration in the reservoir gas $\left(p \mathrm{C} \cdot \mathrm{cm}^{-3}\right)$

$P=$ the dry porosity of the soil (dimensionless)

$\theta=$ the volumetric fraction of moisture in the soil (dimensionless)

$k=(\lambda / 0)^{1 / 2}\left(\mathrm{~cm}^{-1}\right)$

$\lambda=$ radon decay constant $\left(s^{-1}\right)$

$D=$ the bulk diffusion coefficient for radon in soil $\left(\mathrm{cm}^{2} \cdot \mathrm{s}^{-1}\right)$

$x=$ the height of the soil column $(\mathrm{cm})$

A 5-cm sample of gas was withdrawn from the $800-\mathrm{cm}^{3}$ reservoir with a syringe and adsorbed on charcoal. The charcoal was analyzed for radon as described previously, and the amount was divided by the volume of gas withdrawn.

\section{Results of the Laboratory Measurements}

Radon flux measurements were made on 7 defective soil columns and the homogeneous soil columns which served as their controls. The results are shown in Table 4, along with values for $C_{0}, P$ and $\theta$. Radon flux values at the top of the $10-\mathrm{cm}$ soil column were designated $\mathrm{J}_{10}$. Values of $D$ for the soil around a defect were calculated with Equation 9, using data for the corresponding control column. Since the values of $J_{0}$ were different for each source and dependent on the amount of moisture around the radium salts in the base, the attenuation of flux by a soil column was evaluated by calculating the relative flux, $\mathrm{J}_{10} / \mathrm{J}_{0}$.

Despite efforts to achieve significant radon attenuation in the control columns by increasing their moisture content, the relative flux in each of these columns was close to unity, indicating no attenuation. At values for 


\section{TABLE 4. Radon Attenuation and Other Properties of Experimental Soil Columns}

\begin{tabular}{|c|c|c|c|c|c|c|c|c|}
\hline Soil System & $\begin{array}{c}\text { Defect } \\
\text { Dimensions } \\
(\mathrm{cm}) \\
\end{array}$ & $\begin{array}{c}\text { Dry } \\
\text { Porosity } \\
\end{array}$ & $\begin{array}{c}\text { Volumetric } \\
\text { Fraction } \\
\text { Moisture } \\
\theta \\
\end{array}$ & $\begin{array}{c}\text { Reservoir } \\
\text { Concentration } \\
\mathrm{Cg} \\
\left(\mathrm{pCi} / \mathrm{cm}^{3}\right) \\
\end{array}$ & $\begin{array}{c}\text { Diffusion } \\
\text { Coefficient } \\
0 \\
\left(\mathrm{~cm}^{2} / \mathrm{s}\right) \\
\end{array}$ & $\begin{array}{c}\text { Radon Flux } \\
\text { at } x=0 \mathrm{~cm} \\
J_{0} \\
\left(\mathrm{pCi} / \mathrm{cm}^{2} \mathrm{~s}\right) \\
\end{array}$ & $\begin{array}{r}\text { Radon Flux } \\
\text { at } x=10 \mathrm{~cm} \\
J_{10} \\
\left(\mathrm{pCi} / \mathrm{cm}^{2} \mathrm{~s}\right) \\
\end{array}$ & $\begin{array}{c}\text { Relat ive } \\
\text { Flux } \\
\mathrm{J}_{10} / \mathrm{J}_{0}\end{array}$ \\
\hline Defect 1 & $1.5 \times 14 \times 10$ & 0.47 & 0.02 & 330 & 0.032 & 2.2 & 0.66 & 0.3 \\
\hline $\begin{array}{l}\text { Control } \\
\text { for } 1\end{array}$ & - & 0.47 & 0.02 & 2,500 & 0.032 & 3.6 & 3.6 & 1.0 \\
\hline Defect 2 & $0.9 \times 14 \times 10$ & 0.51 & 0.13 & 480 & 0.024 & 4.8 & 2.3 & 0.5 \\
\hline Defect 3 & $0.3 \times 14 \times 10$ & 0.51 & 0.13 & 6,600 & 0.024 & 8.9 & 6.7 & 0.7 \\
\hline Defect 4 & $0.3 \times 14 \times 9$ & 0.51 & 0.13 & 4,500 & 0.024 & 5.6 & 4.4 & 0.8 \\
\hline $\begin{array}{l}\text { Control } \\
\text { for } 2,3 \text {, and } 4\end{array}$ & - n & 0.51 & 0.13 & 3,000 & 0.024 & 3.0 & 3.0 & 1.0 \\
\hline Defect 5 & $0.6 \times 14 \times 10$ & 0.48 & 0.15 & 2,100 & 0.024 & 8.9 & 4.2 & 0.5 \\
\hline Defect 6 & $0.3 \times 14 \times 10$ & 0.48 & 0.15 & 4,300 & 0.024 & 4.8 & 3.7 & 0.8 \\
\hline Defect 7 & $0.3 \times 14 \times 5$ & 0.48 & 0.15 & 11,000 & 0.024 & 5.6 & 6.2 & 1.1 \\
\hline $\begin{array}{l}\text { Control } \\
\text { for } 5,6 \text {, and } 7\end{array}$ & - & 0.48 & 0.15 & 12,000 & 0.024 & 11 & 11 & 1.0 \\
\hline
\end{tabular}


volumetric fraction moisture above 0.2 , control columns dried rapidly at the top; and the radon flux increased erratically. This latter phenomenon was attributed to increased emanation of radon from the hygroscopic radium salts in the source as they absorbed moisture from the soil columns suspended above them. Radon emanation coefficients of uranium-mill tailings have been reported to increase by factors of at least three with increasing moisture content (Strong and Levins 1982). Due to these difficulties, the data shown in Table 4 are limited to soil columns with volumetric fraction moisture less than 0.2 .

The most startling observation was that the relative flux from a defective column was nearly always less than the relative flux from the corresponding control column. Inspection showed that the concentration of radon in the reservoirs below the defective soil columns were generally lower than those below the control column. The only exception was in the reservoir below the control column for defects 2,3 and 4 ; however, the value of $\mathrm{J}_{0}$ for that control column was much lower than those for the corresponding defective columns. A reasonable explanation is that air turbulence in the defect depleted the concentration of radon in the reservoir prior to the flux measurement. During the flux measurements, the concentration gradient of radon across the soil column was reduced below that expected in the absence of turbulence; and the flux was decreased correspondingly. Some flux measurements were made after a defective column had been capped with a bed of coarse charcoal for one hour. Although the relative flux increased, it was still less that the relative flux from its control column.

Examination of the data in Table 4 shows that the relative flux increased with decreasing width of the defect, but it was still less than the flux from its control column with defects only $0.3 \mathrm{~cm}$ in width. It was not eliminated in defects which completely penetrated the column by the placement of a glass fiber filter across the top of the soil column, as in defects 5 and 6 or by a $1-\mathrm{cm}$ layer of soil between the defect and the radon reservoir, as in defect 4. However, the effect was eliminated in defect 7 which only penetrated halfway through the soil column.

The original intent of the experiments with laboratory-scale defects was to test the validity of the theoretical method proposed by Mayer and Zimmerman (1981) to predict the radon flux from defective covers. This simulation does not take into account turbulent diffusion and so cannot be expected to exactly reproduce the values shown in Table 4 . Still, it was of interest to see how close the predicted values would come to those found experimentally. The theoretical method was applied to some of the same soil columns used in the experimental study. Values for $D$ and $J_{0}$ were taken from the experimental data, and values of $\mathrm{C}_{\mathrm{g}}, \mathrm{J}_{10}$, and $\mathrm{J}_{10} / \mathrm{J}_{0}$ were calculated with the aid of the model. The results are shown in Table 5. Theoretical predictions of the relative flux values were generally larger than those measured experimentally. This was expected since the theoretical treatment did not allow for depletion of radon from a soil column due to turbulence prior to the flux measurement. The predicted values for radon concentration in the reservoirs were more puzzling. They were expected to be greater than those found experimentally for the same reason as expressed above. This relationship was found for Defect 5 ; however, the opposite relationship was found for Defect 6 and, particularly, 
TABLE 5

COMPARISON OF THEORETICAL AND EXPERIMENTAL VALUES

OF $\mathrm{J}_{10} / \mathrm{J}_{0}$ AND $\mathrm{C}_{\mathrm{g}}$ FOR DEFECTIVE SOIL COLUMNS

\begin{tabular}{|c|c|c|c|c|c|}
\hline $\begin{array}{l}\text { Soil } \\
\text { System }\end{array}$ & $\begin{array}{l}\text { Defect } \\
\text { Dimensions } \\
\text { (cm) }\end{array}$ & $\begin{array}{c}\mathrm{C}_{\mathrm{g}} \\
\text { Experimental } \\
\left(\mathrm{pc} \mathrm{i} / \mathrm{cm}^{3}\right) \\
\end{array}$ & $\begin{array}{c}\mathrm{C}_{\mathrm{g}_{\text {tical }}} \\
\text { Theoretical } \\
\left(\mathrm{pC} \mathrm{c} / \mathrm{cm}^{3}\right)\end{array}$ & $\begin{array}{c}\mathrm{J}_{10} / \mathrm{J}_{0} \\
\text { Experimental } \\
\end{array}$ & $\begin{array}{c}\mathrm{J}_{10} / \mathrm{J}_{0} \\
\text { Theoretical }\end{array}$ \\
\hline Defect 5 & $0.6 \times 14 \times 10$ & 2,100 & 3,400 & 0.5 & 1.0 \\
\hline Defect 6 & $0.3 \times 14 \times 10$ & 4,300 & 2,000 & 0.8 & 1.0 \\
\hline Defect 7 & $0.3 \times 14 \times 5$ & 11,300 & 2,400 & 1.1 & 1.0 \\
\hline
\end{tabular}

Defect 7. No coherent reason could be found for this discrepancy. It was concluded that the theoretical method could not be accurately tested with the experimental data at hand.

The laboratory experiments indicate that turbulent diffusion of radon occurs in cracks as small as $0.3 \mathrm{~cm}$ in width when the transverse wind velocity across the top of the crack is 1 to 6 miles per hour. Such velocities occur at tailings sites and will undoubtedly increase the rate of radon transport to the surface. The laboratory experiments also show, however, that soil covers as shallow as $5 \mathrm{~cm}$ over the tailings at the bottom of such a crack will greatly inhibit turbulence. Good cover design should make it unlikely that actual defects would penetrate the entire cover for a tailings pile. Also, the radon gas in the tailings will not be as free to diffuse to the defect as it was in the open reservoir used in the experimental study. Both of these factors make it likely that the effect of turbulence on radon transport from centimeterscale defects in the field will be negligible. If wider defects occur, however, turbulence may have a more significant effect. 


\section{AVOIDANCE OF COVER DEFECTS}

The results described in the preceding Sections indicate the complexity and uncertainty in estimating radon emission from cover defects. Thus, it is only prudent to try to avoid the formation of any defects. Fortunately, there are several techniques that can at least help in this endeavour.

Selection of the Cover Soil

The physical and chemical properties of a cover soil are important factors in determining its tendency to form certain types of defects. Shrinkage cracks are generally considered to arise from the contraction of clay particles in soil when it dries, and these particles are characterized by both their physiCal size and chemical composition (Hillel 1980a, Hillel 1980b). The particles have diameters less than $2 \mu \mathrm{m}$ and are composed of secondary minerals, i.e., those formed by weathering and decomposition of primary minerals in the larger silt and sand particles. For engineering purposes, a soil is classified as an inorganic clay if at least $50 \%$ of its weight consists of particles less than 75 $\mu \mathrm{m}$ in size and the plasticity limit and liquid limit of the soil exceed specified values (ASTM 1983a).

Soils rich in clay particles are also very efficient in attenuating radon flux, (Silker and Kalkwarf 1983). They can be compacted to high bulk densities and most importantly, they retain water tenaciously. Both of these factors reduce the diffusion coefficient of radon in the cover soil and thus produce the desired flux attenuation with smaller soil depths.

Fortunately, many inorganic clays can be used as earthen covers for uranium-mill tailings since they do not undergo large volumetric changes with changing water content. A review of literature on clay minerals revealed that their abilities to expand and contract are markedly dependent upon their chemical structures. According to Hillel (1980a), the most prevalent minerals in the clay fraction of temperate-region soils are the aluminosilicates. of these, the smectites have crystal lattices that can expand markedly in contact with water. Examples include montmorillonite, vermiculite and beidellite. Montmorillonite is probably the most widespread in the western United States. Soils containing large amounts of smectic clay are known as vertisols or grumisols, and they are particularly prone to cracking. Shrinkage cracks as wide as $4 \mathrm{~cm}$ and as deep as 1.2 meters in these soils have been reported (Johnson and Hill 1945, Virgo 1981). Clearly, these should be avoided as cover soils.

Probably the simplest method to test the shrinkage potential of a soil is to measure its linear shrinkage by a standard method (ASTM 1983b). Alternatively, candidate cover soils can be rejected on the basis of high smectite concentrations. Several analytical methods have been devised to evaluate the amount of smectite in a sample. These include x-ray diffraction, thermogravimetric analysis, differential scanning calorimetry determination of cationexchange capacity and measurement of water adsorption (Karathanasis and Hajek $1982 \mathrm{a}, 1982 \mathrm{~b})$. 
Sodic soils, i.e., soils with high sodium adsorption ratio, should also be avoided to insure against erosion by runoff water. Beds of these materials can also develop unusual erosion features such as pipes, tubes, tunnels and sinkholes (Gee et. al. 1978). They are particularly prone to erosion by runoff water and should be avoided as cover materials. The sodium adsorption ratio, $S A R$, is given by the equation:

$$
\text { SAR }=\frac{\left[\mathrm{Na}^{+}\right]}{\left(\left[\mathrm{Ca}^{2+}\right]+\left[\mathrm{Mg}^{2+}\right]\right)^{1 / 2}}
$$

where the bracketed quantities are concentrations of the indicated ions that can be leached from the soil with water. A standard method for measuring the SAR of a soil has been described (U.S. Salinity Laboratory Staff 1954), and soils with SAR $>15$ are generally considered to be sodic materials.

Design and Application of the Cover

Probably the most effective way to prevent shrinkage and erosion defects is to use care in the design and application of the cover. Since evaporation of soil moisture is the main cause of shrinkage cracks, efforts should be directed towards inhibiting this process. This can be done by first determining the long-term moisture content of the proposed cover soil at the tailings site. Since an undisturbed bed of the candidate cover soil is likely to be found in the vicinity, determination of its moisture content with depth below the surface should indicate a moisture content that can be maintained for long periods of time in the local climate. Soil at this moisture content should then be compacted to its optimal packing density so that it can act as the main barrier to radon diffusion. This barrier should then be covered with a layer of loose soil to act as a deterrent to water evaporation.

\section{Control of Vegetation Roots}

Root growth of vegetation on soil-covered tailings sites is capable of producing further defects in the cover. Although revegetation of a covered tailings site may be desireable in order to inhibit soil erosion by wind and water, it will also increase the porosity of the soil. At tailings sites in the western United States, natural vegetation such as Russian thistle, sagebrush and rabbit brush have roots tht penetrate to depths of two meters of more (Klepper 1978). When the plants die, the roots are rapidly biodegraded, leaving air-filled channels in the soil through which radon can move rapidly.

A herbicide-delivery system has been developed for the long-term inhibition of root growth at any selected depth below the surface of a soil cover (Cline et al. 1982a, Cline et al. 1982b, Burton et al. 1983). The system consists of a pelletized mixture of polyethylene, carbon black and the herbicide, trifluralin. When the pellets are buried in soil, trifluralin diffuses out slowly and completely inhibits root growth for a distance of about $4 \mathrm{~cm}$ around each pellet. The system is designed so the effusion rate of trifluralin from a pellet matches the biodegradation rate of this herbicide in soil, so that an effective concentration of herbicide is continually maintained 
in the soil. Cylindrically shaped pellets, $9 \mathrm{~mm} \times 9 \mathrm{~mm}$ in size, can hold sufficient trifluralin to deliver root-inhibiting concentrations of the herbicide for about 100 years.

Field tests of this system at an inactive tailings site showed that a single layer of pellets spaced $5 \mathrm{~cm}$ apart and about $1 \mathrm{~m}$ below the surface of a cover soil were behaving as expected after 8 months. Concentrations of trifluralin in the soil were sufficient to act as a barrier to root penetration beyond that level. Using this technique, revegetation can still be accomplished at the surface; but root penetration can be confined to a selected depth.

\section{Control of Animal Burrows}

Defects can also be formed in soil covers by deep-burrowing insects or mammals that are native to the area. The potential effects of several common species at mill sites in the western United States have been described (cline et al. 1982). Townsend ground squirrels dig burrows that range up to $1 \mathrm{~m}$ in length, but a $15-\mathrm{cm}$ layer of crushed stones, 2 to $3 \mathrm{~cm}$ in diameter, was found to be an effective barrier to these rodents. However, this size of barrier was not found to be effective against praire dogs which are about 6 times heavier than the ground squirrels and form burrows as long as $5 \mathrm{~m}$. No other methods were tested for preventing prairie dogs from digging burrows; but sustainedrelease preparations of rodenticides have been described which may offer a solution for at least several years (Scher 1977). Tunneling by ants also presents a potential problem. Several species were reported to form tunnels over $1 \mathrm{~m}$ in length, but no methods for preventing the formation of these tunnels were tested (Cline et al. 1982). Sustained-release preparations of insecticides may prove useful in this case, and their preparation and properties have been described elsewhere (Cardarelli 1976). 


\section{REFERENCES}

American Society for Testing and Materials 1983a. "Standard Test Method for Classification of Soils for Engineering Purposes, D2487-69". In 1983 Annual Book of ASTM Standards, Volume 04.08; Soil and Rock; Building Stones, pp. 392-366, American Society for Testing and Materials, Philadelphia, Pennsylvania.

American Society for Testing and Materials 1983b. "Standard Text Method for Shrinkage Factors of Soils, D427-61". In 1983 Annual Book of ASTM Standards, Volume 04.08; Soil and Rock; Building Stones, pp. 136-137, American Society for Testing and Materials, Philadelphia, Pennsylvania.

Burton, F. G., D. A. Cataldo, J. F. Cline, and W. E. Skiens. 1983. "The Use of Controlled Release Herbicides in Waste Burial Sites." In Controlled Release Delivery Systems, T. J. Roseman and S. Z. Mansdorf (Editors), pp. 291-300, Marcel Dekker, Inc., New York City, New York.

Cardarelli, N. 1976a. "Other Controlled Released Pesticide Areas and New Dispersing Systems-Rodenticides". In Controlled Release Pesticide Formulations, Pp.159-160, CRC Press, Cleveland, Ohio.

Cardarelli, N. 1976b. "Controlled Release Insecticides". In ControlledRelease Pesticide Formulations, Pp. 133-157, CRC Press, Cleveland, Ohio.

Cline, J. F., F. G. Burton, D. A. Cataldo, W. E. Skiens and K. A. Gano. 1982a. Long-Term Biobarriers to Plant and Animal Intrusions of Uranium Tailings. PNL-4340, (D0E/UMT-0209), Pacific Northwest Laboratory, Richland, Washington.

Cline, J. F., D. A. Cataldo, W. E. Skiens, and F. G. Burton. 1982b. "Biobarriers Used in Shallow Burial Ground Stabiization." Nuclear Technol. 58:150-153.

Gee, G. W., A. Bauer and R. D. Decker. 1978. "Physical Analyses of Overburden Materials and Mine Land Soils". In Reclamation of Drastically Disturbed Lands Disturbed, Pp. 665-686. American Society of Agronomy, Crop Science Society of America, Soil Science Society of America, Madison, Wisconsin.

Hillel, D. 1980a. "Nature and Behavior of Clay". In Fundamentals of Soil Physics, Pp. 71-92, Academic Press, New York City, New York.

Hillel, D. 1980b. "Evaporation from Irregular Surfaces and Shrinkage Cracks". In Applications of Soil Physics, pp. 135-137. Academic Press, New York City, New York.

Johnston, J. R. and H. 0. Hill. 1945. "A Study of the Shrinkage and Swelling of Rendzina Soils". Soil Sci. Soc. Am. Proc. 9:24-29. 
Karathansis, A. D. and B. F. Hajek. 1982a. "Revised Methods for Rapid Quantitative Determination of Minerals in Soil Clays". Soil Sci. Soc. Am. J. $46: 419-425$.

Karathansis, A., D. and B. F. Hajek. 1982b. "Quantitative Evaluation of Water Adsorption of Soil Clays". Soil Sci. Soc. Am. J. 46:1321-1325.

Kimbal1, B. A. 1983. "Canopy Gas Exchange: Gas Exchange with Soil". Part III: In the Soil". In Limitations to Efficient Water Use in Crop Production, H. M. Taylor, W. R. Jordan and T. R. Sinclair (Editors), pp. 215-225. American Society of Agronomy, Madison, Wisconsin.

Klepper, B., L. E. Rogers, J. D. Hedlund, R. G. Schreckhise and K. R. Price. 1978. "Radiocesium in a Gray Rabbit Brush Community". In Environmental Chemistry and Cyclic Processes, CONF-760429, pp. 725-737, Technical Information Center, U.S. Department of Energy, Washington, D. C.

Landman, K. A. 1982. "Diffusion of Radon Through Cracks in a Concrete Slab". Health Physics. 43:(1)65-71.

Landman, K. A. and D. S. Cohen. 1983. "Transport of Radon Through Cracks in a Concrete Slab. Health Phys. 44:(3)249-257.

Mayer, D. W. and D. A. Zimmerman. 1981a. Radon Diffusion Through Uranium Mill Tailings and Cover Defects. NUREG/CR-2457, (PNL-4063), U.S. Nuclear Regulatory Commission, Washington, D. C.

Mayer, D. W., C. A. Oster, R. W. Nelson and G. W. Gee. 1981b. Radon Diffusion Through Multilayer Earthen Covers: Models and Simulations. PNL-8989, Pacific Northwest Laboratory, Richland, Washington.

Nelson, R. W.., G. W. Gee and C. A. Oster. 1980. "Radon Control by Multilayer Earth Barriers, 1. Modeling of Moisture and Density Effects on Radon Diffusion from Uranium Mill Tailings." In Uranium Mill Tailings Management, Proceedings of the Third Symposium, November 24-25, 1980, pp. 79-88. Geotechnical Engineering Program, Civil Engineering Department, Colorado State University.

Rogers, V. C. and K. K. Nielson. 1981. A Handbook for the Determination of Radon Attenuation Through Cover MateriaTs. NUREG/CR-2340, (PNL-4084, RAE 181),, U.S. Nuclear Regulatory Commission, Washington, D. C.

Rogers, V. C., K. K. Nielson, D. C. Rich, G. M. Sandquist and M. L. Mauch. 1982. Radon Attenuation With Earthen Covers, 1982 Annual Report to the U.S. Department of Energy on UMTRAP Technology Development, RAE-33-14, Rogers and Associates Engineering Corporation, Salt Lake City, Utah.

Scher, H. B. 1977. Controlled Release Pesticides. ACS Symposium Series 53. American Chemical society, Washington, D. C. 
Silker, W. B. 1981. A Radon Attenuation Test Facility. NUREG/CR-2243 (PNL$3899)$, U.S. Nuclear Regulatory Commission, Washington, D. C.

Silker, W. B. and D. R. Kalkwarf. 1983. Radon Diffusion in Candidate Soils for Covering Uranium Mill Tailings. NUREG/CR-2924, (PNL-4434), U.S. Nuclear Regulatory Commission, Washington, D. C.

Strong, K. P. and D. M. Levins. 1982. "Effect of Moisture Content on Radon Emanation from Uranium Ore and Tailings." Health Phys. 42:27-32.

U.S. Nuclear Regulatory Commission. 1980. Generic Environmental Impact Statement on Uranium Milling. NUREG-0706, U.S. Nuclear Regulatory Commission, Washington, D. C.

U.S. Salinity Laboratory Staff. 1954. Diagnosis and Improvement of Saline and Alkali Soils. Agriculture Handbook 60, U. S. Department of Agriculture, Beltsville, Maryland.

Virgo, K. J. 1981. "Observations of Cracking in Somali Vertisols." Soif Sci. 131:60-61. 
NUREG/CR-3395

PNL -4776

\section{DISTRIBUTION}

No. $0 f$

Copies

\section{OFFSITE}

U.S. Nuciear Regulatory Commission Division of Technical Information and Document Control 7920 Norfolk Avenue Bethesda, MD 20014

10 George F. Birchard U. S. Nuclear Regulatory Comm. 1130-SS Washington, DC 20555

1 V. C. Rogers

Rogers \& Assoc. Eng. Corp.

P. 0. Box 330

Salt Lake City, UT 84110

1 K. K. Nielson

Rogers \& Assoc. Eng. Corp.

P. 0. Box 330

Salt Lake City, UT 84110

\section{ONSITE}

34 Pacific Northwest Laboratory

J. M. Nielsen

R. W. Perkins

W. D. Felix

N. A. Wogman

G. W. Gee

J. N. Hartley

P. 0. Jackson

D. R. Kalkwarf

D. W. Mayer

R. W. Nelson

M. G. Foley

V. W. Thomas

W. I. Enderlin

J. A. Glissmeyer

P. L. Koehmstedt

Publishing Coordination

Technical Information 


\begin{tabular}{|c|c|}
\hline $\begin{array}{l}\text { U.S. NUCLEAR AEGULATOAY COMMISSION } \\
\text { BIBLIOGRAPHIC DATA SHEET }\end{array}$ & 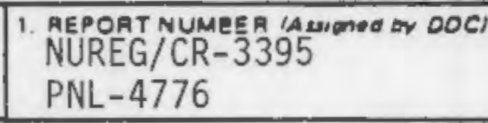 \\
\hline \multirow{2}{*}{ 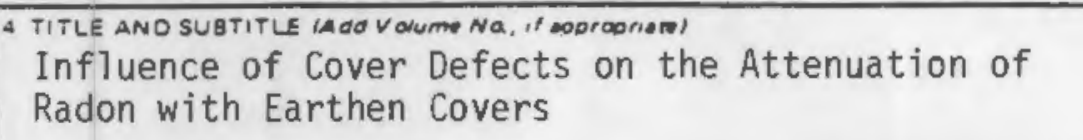 } & 2. (Lewe olenk) \\
\hline & 3. RECIPIENT'S ACCESSION NO. \\
\hline D. R. Kalkwarf and D. W. Mayer & $\begin{array}{l}\text { 5. OATE REPORT COMPLETED } \\
\text { AONTH } \\
\text { AuguSt }\end{array}$ \\
\hline \multirow{3}{*}{$\begin{array}{l}\text { 9. PERFORMING ORGANIZATION NAME AND MaILING RODRESS IInciud Zio Code' } \\
\text { Pacific Northwest Laboratory } \\
\text { P. 0. BoX } 999 \\
\text { Richland, WA } 99352\end{array}$} & \begin{tabular}{l|l}
\multicolumn{2}{|c|}{ DATE AEPOAT ISSUED } \\
MONTH \\
NOVEmber & TYEAR \\
\end{tabular} \\
\hline & 6. (Leavonk) \\
\hline & 8. (Leave orent) \\
\hline \multirow{2}{*}{ 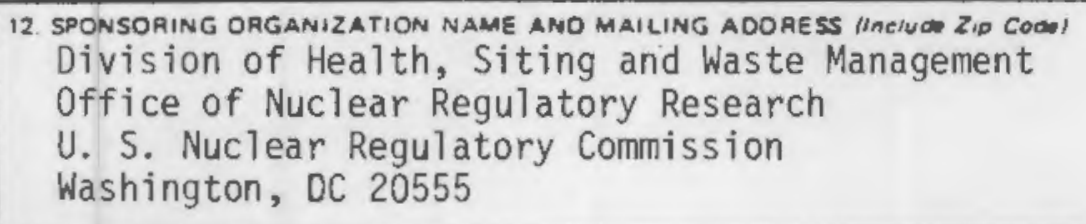 } & 10. PAOJECT/TASK/WORK UNIT NO. \\
\hline & $\begin{array}{l}\text { 11. FIN NO. } \\
\text { B2269 }\end{array}$ \\
\hline
\end{tabular}

\begin{tabular}{l|l}
\hline 13. TYPE OF REPORT & PE AIOD COVEREO HnCiUsive aOARS \\
Topical Technical Report &
\end{tabular}

\begin{tabular}{|l|l|l}
\hline 15. SUPPLEMENTARY NOTES & 14. Heme denkI
\end{tabular}

16. ABSTRACT 200 woros ar iessi

Experimental and theoretical evaluations of radon flux through laboratory-scale defective soil columns are presented together with a survey of literature on the formation and prevention of defects in soil covers. Probable defects in earthen covers for uranium-mill tailings include shrinkage and erosion cracks, erosion piping, animal burrows and air channels formed by the biodegradation of vegetation roots. Calculations based on mathematical models indicated that collections of defects which could increase the radon flux from an earthen cover by a factor of two would be easily detected by visual inspection. However, these models ignore air turbulence in the defect and more-rapid drying of soil around the defect. Both of these processes can enhance radon flux to the surface. Consequently, recommended methods to inhibit defect formation should be applied.

17 KEY WOROS ANO OOCUMENT ANALYSIS 172 OESCRIPTOAS

Radon, radon attenuation, defective soil covers

170. IOENTIFIEAS: OPEN.ENOE O TEAMS

:8. AVAILABILITY STATEMENT

unlimited

\begin{tabular}{|c|c|}
\hline $\begin{array}{l}19 \text { SECUA'TY CLASS mp's reoort } \\
\text { unClaSSitied }\end{array}$ & 21 NO OF PAGES \\
\hline 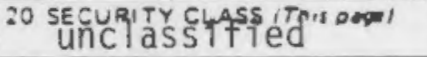 & $\begin{array}{l}22 . \text { PRICE } \\
5\end{array}$ \\
\hline
\end{tabular}




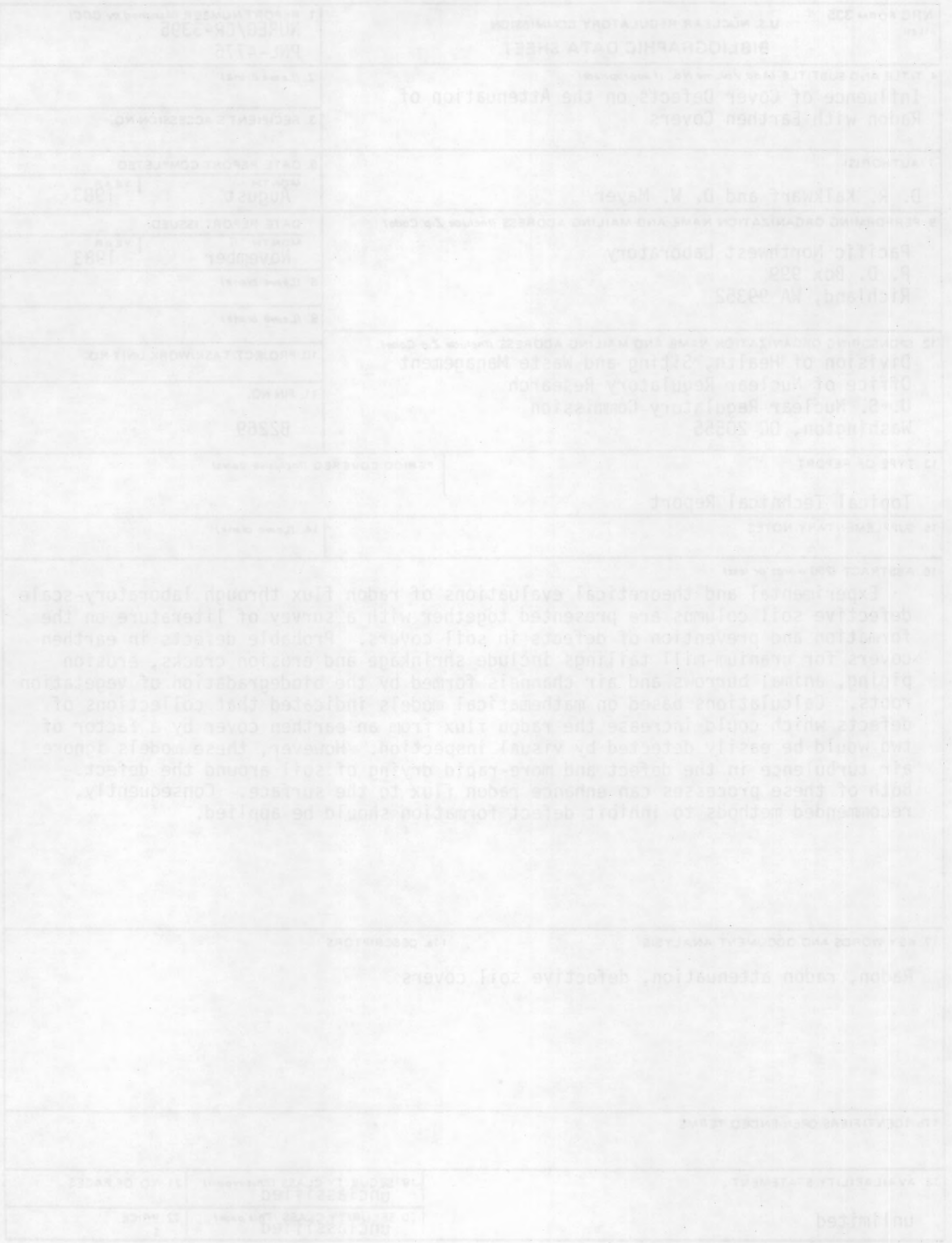

